\title{
V6 Desenvolvimento do processo "downstream" na produção de uma vacina tetravalente recombinante contra dengue
}

\author{
Anna Paula Yorio ${ }^{1}$, Maria Carolina de Souza Martins ${ }^{1}$, André Tavares \\ da Silva Fernandes ${ }^{1}$, Márcia Archer ${ }^{1}$ \\ ${ }^{1}$ Bio-Manguinhos, Fiocruz, RJ
}

Introdução: O desenvolvimento de uma vacina tetravalente que confira imunidade protetora de longa duração contra os quatro sorotipos do vírus da dengue é uma das prioridades da OMS. Atualmente, algumas vacinas contra dengue estão em teste, entre elas, a vacina quimérica de vírus vivo atenuado que utiliza, como vetor viral, o vírus vacinal da febre amarela. A produção do vírus quimérico ocorre em células de origem animal e as diretrizes para produção de vacina de vírus vivo atenuado exigem que a concentração de DNA residual celular seja menor que $10 \mathrm{ng} /$ dose. Para alcançar tal objetivo, é necessário que a suspensão viral passe por processos de clarificação e purificação.

Objetivo: Estabelecer a metodologia de purificação viral para a vacina quimérica contra dengue, visando atender às diretrizes para produção de vacina de vírus vivo atenuado.

Metodologia: O processo de clarificação viral elimina as células em suspensão e os restos de células mortas. Este processo pode ser feito por filtração com membrana de $0,45 \mu \mathrm{m}$ ou por centrifugação a $437 \mathrm{G}$ por 10 minutos. Para diminuir a concentração de DNA celular residual, foram testados diferentes esquemas de purificação. Após a escolha do melhor esquema, testamos três concentrações e três tempos de incubação para o sulfato de protamina $(0,5 ; 2,0$ e $5,0 \mathrm{mg} / \mathrm{ml}$ por $30 \mathrm{~min}$, $1 \mathrm{~h}$ e $2 \mathrm{~h}$ ) e para Benzonase ${ }^{\circledR}(9 ; 15$ e $25 \mathrm{un} / \mathrm{ml}$ por $6 ; 16$ e $30 \mathrm{~h})$ para os quatro sorotipos do vírus quimérico dengue. A concentração de DNA residual e o título viral das amostras antes e depois do tratamento foram quantificados, este por ensaio de placa de lise e aquela por colorimetria.

Resultados: No teste dos diferentes esquemas de purificação, observamos que, no tratamento com sulfato de protamina, a etapa de centrifugação após o tratamento pode ser substituída pela filtração, sem perda de eficiência na diminuição na concentração de DNA residual. No esquema com a Benzonase $\AA$, observamos que o tempo de $3 \mathrm{~h}$ apresentou melhor resultado que os tempos menores, sendo, ainda assim, menos eficiente do que o sulfato de protamina. Nos testes com diferentes concentrações e tempos de incubação em gelo, não foram observadas diferenças significativas entre as concentrações e os tempos, por outro lado, o sulfato de protamina foi capaz de reduzir a níveis menores a concentração de DNA residual, independentemente 
da concentração de DNA residual inicial, quando comparado à Benzonase ${ }^{\circledR}$.

Conclusão: Diante destes resultados, podemos concluir que o sulfato de protamina e a Benzonase ${ }^{\circledR}$ são eficientes para reduzir a concentração de DNA residual em concentrações e nos tempos menores testados e que a etapa de centrifugação pode ser retirada do esquema de purificação com sulfato de protamina.

Palavras-Chave: Vacina Quimérica, Dengue, Purificação Viral 